Terbit online pada laman web jurnal: http://journal.isas.or.id/index.php/JASENS

\begin{tabular}{c}
\hline JOURNAL OF APPLIED SMART ELECTRICAL \\
NETWORK AND SYSTEMS (JASENS) \\
\hline ISAS
\end{tabular}

\title{
Analisis Energi Baru Terbarukan Untuk Sistem Kelistrikan Desa
}

\author{
Aesha Fathara \\ Program Studi Magister Teknik Elektro, Fakultas Teknik Universitas Tanjungpura \\ aeshafathara@gmail.com
}

\begin{abstract}
Electricity is a primary need for society. Energy that will never run out of availability is energy from solar radiation. Indonesia is an agricultural country that can utilize alternative energy by utilizing biomass energy, one of which is rice husk and straw waste. Based on data from the BMKG Paloh Station, Sambas Regency has a fairly large intensity of sunlight because it is located just below the equator. The intensity of light in the dry season can reach 6 hours in a period of 8 hours of sunlight, namely from $8.00-16.00$. The resulting energy conversion is $38.01 \mathrm{mj} / \mathrm{m} 2 /$ day. Meanwhile, for the biomass potential from the BPS data of Sambas Regency in Tebas District, there are 6,730 ha of rice fields, which can produce 403 tons of rice husk and straw waste in one day for 1 year and can produce 5 million $\mathrm{Mj} /$ day . By using HOMER Software. The results of the conversion analysis of the optimization of renewable energy for power plants that have an annual peak power of $45 \mathrm{~kW}$ and daily energy consumption of $330 \mathrm{kWh} /$ day obtained the most optimal potential for rice husk and straw waste, which requires an initial capital of $\$ 67,120$ with a total net present minimum cost (NPC). Electricity from the system cost is also minimum at US\$ $0.005 / \mathrm{kWh}$. And in technical economic analysis, modeling this system requires a payback period of about 11 years without grid bills and 5 years with grid bills. Meanwhile, conversion using PV requires larger capital and longer payback.
\end{abstract}

Keywords: solar energy, biomass, rice husk and straw, homer, village electricity

\begin{abstract}
Abstrak
Listrik merupakan kebutuhan primer bagi masyarakat. Untuk mengatasi masalah energy yang dapat dijadikan energi terbarukan. Energi yang tidak akan pernah habis ketersediaannya adalah energy dari radiasi sinar matahari. Indonesia negara agraris dapat memanfaatkan energi alternatif dengan pemanfaatan energy biomassa, salah satunya limbah sekam padi dan jerami. Berdasarkan data dari BMKG Stasiun Paloh, Kabupaten Sambas memiliki intensitas sinar matahari yang cukup besar dikarenakan terletak tepat dibawah garis katulistiwa. Intensitas cahaya pada musim kemarau bias mencapai 6 jam dalam periode waktu 8 jam penyinaran matahari yaitu dari jam 8.00 - 16.00. Jika di konversikan dapat menghasilkan energi sebesar 38,01 $\mathrm{mj} / \mathrm{m} 2 /$ hari. Sedangkan untuk potensi biomassa dari data ang diperoleh dari BPS Kabupaten Sambas di Kecamatan Tebas terdapat lahan sawah seluas 6.730 ha. Dari luas tanah persawahan tersebut dapat menghasilkan 403 ton limbah sekam padi dan jerami dalam satu hari selama 1 tahun dapat menghasilkan 5 juta $\mathrm{Mj} /$ hari. Dari data potensi dikonversikan menggunakan Software HOMER. Hasil dari analisis konversi optimalisasi energi terbarukan untuk pembangkit tenaga listrik yang memiliki puncak daya tahunan $45 \mathrm{~kW}$ dan konsumsi energi harian $330 \mathrm{kWh} /$ hari didapatkan bahwa potensi limbah sekam padi dan jerami adalah yang paling optimal, yaitu hanya memerlukan modal awal (initial capital) sebesar \$ 67.120 dengan total net present cost (NPC) minimum. Listrik dari biaya sistem juga minumum yaitu sebesar US \$ 0,005/kWh. Dan dalam analisis ekonomi teknik, pemodelan sistem ini memerlukan waktu balik modal yaitu sekitar 11 tahun tanpa tagihan grid dan 5 tahun dengan tagihan grid. Sedangkan konversi menggunakan PV di perlukan Modal yang lebih besar dan balik modal lebih lama.
\end{abstract}

Kata kunci: Energi matahari, Biomassa, Sekam padi dan Jerami, HOMER, Listrik desa.

Diterima Redaksi : 24-05-2021 | Selesai Revisi : 21-06-2021 | Diterbitkan Online :30-06-2021

\section{Pendahuluan}

Perusahaan Listrik Negara (PLN) sebagai pemasok utama listrik di tanah air belum mampu memenuhi permintaan listrik di masyarakat. Krisis energi listrik yang terjadi di Indonesia disebabkan oleh Berdasarkan data yang dilansir oleh Badan Pusat ketergantungan Indonesia terhadap bahan bakar fosil. Statistik (BPS) tahun 2018 menunjukkan bahwa Hal ini telah mendorong untuk mengatasi masalah energi produksi padi di Indonesia sebanyak 56,54 juta ton, bersama-sama. Penghematan pada bahan bakar fosil untuk daerah Kalimanta Barat sendiri menghasilkan 1,6 
juta ton padi. Dari proses penggilingan padi dapat Kadar Air Yang Hilang (\%) Variasi Campur 2 Juli 2014 diperoleh sekam sekitar 20-30\% dari bobot Afif Almu, Syahrul, Yesung: Analisa Nilai K 122 ir pada gabah.Namum kesediaan limbah yang melimpah ini briket wa kandungan rtinggi dengan pel (D 1:2) dan (A tidak dimanfaatkan secara maksimal, maka hal inilah 1:1) yaitu kinan dapat besarnya masing-masing bkan yang dapat mendorong untuk memanfaatkan limbah karena mpuran kanji, u sekam padi pencampuran i sekam padi tersebut sebagai energi alternatif khususnya penyerapan setiap sampel apat dari briket ng dan abu (C di wiliyah yang mengalami kekurangan pasokan listrik. 3:1) yaitu edangkan nilai cil didapat dari 3) yaitu hanya

Pada tahun 2017 ada lebih dari 2.500 desa di Indonesia yang belum dialiri listrik[1]. Di beberapa wilayah yang saat ini kekurangan pasokan energi listrik sebagaimana terjadi di daerah Sumatera, Kalimantan, dan Papua.Kondisi ini menyebabkan daerah-daerah tersebut Tumbuhan menyerap energi dari matahari melalui sulit untuk berkembang, baik secara ekonomi, sosial proses fotosintesis,penelitian yang dilakukan oleh maupun budaya, hal ini yang perlu segera dicari jalan Untoro Budi pada tahun 2010 pada tongkol jagung keluarnya.

Sehingga dalam penelitian ini bertujuan untuk menganalisis sumber daya energi alternatif yang dihasilkan limbah sekam padi dan jerami,mengetahui potensi kesediaan bahan bakar alternatif dari radiasi matahari serta limbah sekam padi dan jerami.serta memahami konfigurasi software Homer terbaik dari limbah sekam padi dan jerami serta biomassa dalam penyediaan energi alternatif endah didapat yamplung dan ampel (C 3:1) 0156 $\mathrm{gr} /$ detik. $n$ briket paling engan sampel $6 \mathrm{gr} /$ detik. adar air briket at dari briket yamplung dan ampel (A 1:1) \%. Sedangkan adar air briket briket dengan $\mathrm{r} 36,60 \%$ [3].

Oleh T Iskandar,dalam penelitian tentang pemanfaatan limbah pertanian sebagai energi alternatif Sehingga muncul metode untuk mengatasi permasalahan di atas dan agar dapat memenuhi kebutuhan listrik di desa tersebut, maka diperlukan suatu studi kelayakan sistem untuk menggabungkan energi sinar matahari dan energi bah biomasa agar dapat menciptakan kombinasi energi alternatif yang optimal[2]. Oleh karena itu penelitian ini menggunakan pemodelan program komputer yaitu, software Homer untuk merancang dan menguji kelayakan sumber energi alternatif. Dengan menggunakan software Homer diharapkan proses studi kelayakan ini menjadi lebih efektif dan efisien.

\subsection{Biomassa}

adanya pengaruh suhu selama proses karbonisasi dan tekanan pada saat pembriketan terhadap sifat pembakaran briket dari tongkol jagung. Pada penelitian ini, proses karbonisasi dilakukan pada suhu $220^{\circ} \mathrm{C}$, $300^{\circ} \mathrm{C}$ dan $380^{\circ} \mathrm{C}$ sementara proses pembriketan dilakukan pada tekanan 24,4 MPa, 48,8 MPa, 73,2 MPa, dan 97,6 MPa. Hasil penelitian menunjukkan bahwa proses karbonisasi yang dilakukan dapat meningkatkan kandungan karbon dan nilai kalor briket dari tongkol jagung. Kondisi operasi karbonisasi terbaik diperoleh pada suhu $380^{\circ} \mathrm{C}$, sementara untuk pembriketan dilakukan pada 97,6 MPa yang dapat menaikkan kadar karbon sampai $67 \%$ dan nilai kalor sampai $65 \%$. Proses karbonisasi yang dilakukan dapat mengurangi emisi CO dan laju pembakaran. Hasil penelitian juga menunjukkan bahwa penekanan yang tinggi selama pembriketan juga dapat mengurangi emisi CO dan laju pembakaran [4].

\subsection{Proses Gasifikasi}

Proses konversi secara termo-kimia (pirolisa-reduksioksidasi) yang menggunakan panas untuk merubah biomassa padat atau padatan berkarbon lainnya menjadi gas sintetik (menyerupai gas alam) yang mudah terbakar. Proses gasifikasi berlangsung dalam keadaan kekurangan/miskin oksigen. Proses gasifikasi dapat Biomassa material organik dari tumbuh dan hewan. merubah hampir semua bahan organik padat menjadi gas Biomassa menyimpan energi dari matahari. (Wikipedia, bakar yang bersih dan netral. Gasifikasi biomassa boleh 2019). pada penelitian dengan judul analisa nilai kalor dipahami sebagai reaksi oksidasi parsial biomassa dan laju pembakaran pada briket campuran biji menghasilkan campuran gas yang masih dapat nyamplung (calophyllm inophyllum) dan abu sekam dioksidasi lebih lanjut (bersifat bahan bakar)

padi oleh M. Afif Almu, Syahrul, Yesung Allo Padangyang dilakukan pada tahun 2014 bahwasannya Nilai Kalor paling besar didapa campuran buah nyamplung sekam padi pada sampel (C sebesar 4.792,40 $\mathrm{cal} / \mathrm{gr}$. Sed kalor briket yang paling kecil briket dengan sampel (E 1:3) sebesar 3.431,00 cal/gr. 2. Laju pembakaran paling rend dari briket campuran buah nya abu sekam padi dengan sam yaitu hanya sebesar 0,001 Sedangkan laju pembakaran tinggi didapat dari briket den (A 1:1) yaitu sebesar 0,00246 g 3. Persentase pengeringan kada yang paling rendah didapat dengan campuran buah nya abu sekam padi dengan sam yaitu

Irhan Febijanto, melakukan penelitian tentang pemanfaatan potensi limbah biomasa sebagai energi pengganti fosil yang cadangannya semakin menipis. Limbah biomasa ini dihasilkan dari proses produksi pada kegiatan agro-industri. Data limbah biomasa didapat dari rasio umum terhadap jumlah tanaman atau jumlah produksi. Setelah diketahui potensi limbah biomasa di suatu propinsi dilakukan survey ke sumber penghasil libah biomasa tersebut, juga ditindak lanjuti survei ke pabrik/perkebunan penghasil tanaman tersebut untuk melakukan konfirmasi keberadaan limbah biomasa.[5] hanya sebesar $21,52 \%$. persentase pengeringan kada Dalam penelitian ini limbah tanaman yang digunakan paling tinggi terdapat pada br sampel (D 1:2) yaitu adalah kelapa sawit, tebu, karet, kelapa, kayu, padi, sebesar 30510152025303540 A 1:1 B 2:1 C 3:1 D ketela, jagung, penelitian ini menggunakan pemanfaatan

Journal of Applied Smart Electrical Network and Systems (JASENS) 
mekanisme CDM (Clean Development Mechanism). sekam padi: arang kayu (70:30)\% sebagai perlakuan Dengan pemanfaatan mekanisme ini akan didapat D.[7] pengkajian kemungkinan adanya aliran investasi asing dan terjadinya transfer teknologi dari luar ke dalam negeri. Kemungkinan-kemungkinan ini sangat menguntungkan bagi negara berkembang seperti Indonesia yang masih kekurangan finansial dalam pemanfaatan energi-energi terbarukan.

Nuyah dan Nesi S, didalam penelitian ini penulis membahas tentang pemanfaatan abu sekam padi pada pembuat tegel karet. Penelitian ini dilakukan untuk mengetahui pengaruh penggunaan abu sekam padi sebagai bahan pengisi pada pembuatan tegel karet, serta mendapatkan formula tegel karet yang tepat dan Pembangkit listrik energi terbarukan pada umumnya memenuhi persyaratan SNI Tegel Karet (SNI 03-1550mempunyai skala yang kecil, tidak lebih dari 10 MW. 1989) dan Karpet Karet (SNI 12-1000-1989). Jenis Dengan skala yang kecil ini, kemungkinan nilai IRR bahan pengisi yang digunakan dalam penelitian ini (Internal Rate of Return) dari suatu proyek relatif kecil. adalah abu sekam padi, dengan variasi perbandingan Dengan menggunakan skema CDM, IRR suatu proyek yaitu formula 1 (abu sekam padi : kaolin $=35 \mathrm{phr}: 70$ energi terbarukan akan dapat ditingkatkan, dengan phr), formula 2 (abu sekam padi : kaolin $=40 \mathrm{phr}: 65$ adanya tambahan penghasilan dari hasil pengurangan phr), formula 3 (abu sekam padi : kaolin $=45 \mathrm{phr}: 60$ emisi $\mathrm{CO} 2$ yang dihasilkan dari pembangunan proyek phr), formula 4 (abu sekam padi : kaolin $=50 \mathrm{phr}: 55$ yang menggunakan limbah biomasa. Penambahan IRR phr), dan formula 5 (abu sekam padi : (kaolin $=55 \mathrm{phr}$ : ini akan dapat meningkatkan daya tarik proyek $50 \mathrm{phr}$ ).[8] pemanfaatan limbah biomasa.

Arie Febrianto, penelitian ini membahas tentang pemanfaatan kulit buah nipah sebagai sumber energy alternatif. Penelitian ini bertujuan untuk memperoleh kombinasi perlakuan yang terbaik antara jumlah perekat pati tapioka dan bahan tambahan kapur untuk dapat menghasilkan briket arang yang dapat dimanfaatkan sebagai sumber energi alternatif dan untuk mengetahui biaya produksi yang dibutuhkan untuk pembuatan briket bioarang kulit buah nipah. Rancangan percobaan menggunakan 2 faktor yaitu konsentrasi perekat pati tapioka $(\mathrm{P})$ dan konsentrasi bahan imbuh kapur $(\mathrm{K})$ yang masing-masing terdiri dari 3 level yaitu P1 $(20 \%), \mathrm{P} 2$ (30\%), dan P3 (40\%); K1 (1\%), K2 (3\%), K3 (5\%) yang diulang sebanyak 2 kali.

\section{Metode Penelitian}

Metode yang digunakan pada penelitian ini adalah menggunakan metode kuantitatif dan mencakup dua tahap, yaitu studi kelayakan potensi energi biomassa dan surya matahari yang terletak di kecamatan Tebas dan Kabupaten Sambas, studi beban listrik di Dusun Pelanjau yang terletak di Desa Bukit Sigoler, Kecamatan Tebas, Kabupaten Sambas.

\subsection{Pengukuran Beban}

Penghitungan beban listrik sangat diperlukan untuk mengetahui beban yang akan diperlukan. Metode yang digunakan pada pengumpulan data beban listrik di Dusun Pelanjau RT 13 Sukadamai, Desa Bukit Sigoler, Kecamatan Tebas, Kabupaten Sambas adalah dengan Pengamatan dilakukan pada rendemen produk, kadar air, metode sampling. Sampling yang digunakan adalah ketahanan tekan, nilai kalor, dan kadar abu. Hasil dengan memilih beberapa rumah warga yang terletah di penelitian menunjukkan bahwa perlakuan terbaik adalah Dusun Sukabaru dikarenakan dusun tersebut merupakan perlakuan penambahan konsentrasi perekat pati tapioka dusun yg terletak cukup dekat dengan Dusun Pelanjau. $20 \%$ dan konsentrasi kapur 5\%. Perlakuan terbaik Bila penulis bermaksud meneliti sebagian populasi saja mempunyai rendemen produk $78.04 \%$, kadar air $4.10 \%$, maka sebaiknya jumlah minimal sample yang baik ketahanan tekan $157.57 \mathrm{~N} / \mathrm{cm} 2$, nilai kalor 2753.71 digunakan adalah $10 \%$ dari jumlah populasi yang ada. $\mathrm{kal} / \mathrm{g}$, dan kadar abu sebesar $22.35 \%$. Hasil analisis biaya Kemudian wawacara dilakukan dengan kepala Desa produksi diperoleh HPP sebesar sebesar Rp. 1120.23 per Bukit Sigoler mengenai peralatan elektronik dan kilogram dengan harga jual Rp. 1700 per kilogram konsumsi listrik setiap harinya

dengan mark up $40 \%$, sehingga diperoleh BEP (unit) 11986.03 kilogram atau sebesar Rp. 20252297.18 [6].

Jalal Rosyidi, penelitian ini membahas tentang perbandingan antara briket-briket berbahan dasar sekam padi sebagai energy alternatif. Penelitian ditujukan untuk mengetahui karakteristik briket-briket berbahan dasar sekam padi dan telah dilaksanakan di Laboratorium Biofisika Jurusan Fisika Fakultas MIPA Universitas Jember dan UPT.PKB Dinas Perhubungan Homer mensimulasikan dan mengoptimalkan sistem Jember. Bahan penyusun briket yang digunakan adalah pembangkit listrik baik stand-alone maupun grid sekam padi (100\%) sebagai perlakuan A, arang sekam connected yang dapat terdiri dari kombinasi turbin padi $(100 \%)$ sebagai perlakuan $\mathrm{B}$, arang sekam padi: angin, photovolaic, mikrohidro, biomassa, generator arang kayu (50:50)\% sebagai perlakuan $\mathrm{C}$, dan arang (diesel/bensin), microturbine, fuel-cell, baterai, dan penyimpanan hidrogen, melayani beban listrik maupun 
termal. Dengan HOMER, dapat diperoleh spesifikasi paling optimal dari sumber energi - sumber energi yang mungkin diterapkan.

Kriteria dari sistem teroptimal itu sendiri adalah simulasi yang memiliki nilai net presents costs (NPC) paling rendah. Saat melakukan simulasi, HOMER menentukan semua konfigurasi sistem yang mungkin, kemudian ditampilkan berurutan menurut NPC (atau disebut juga life cycle costs). Jika analisa sensitivitas diperlukan, HOMER akan mengulangi proses simulasi untuk setiap variabel sensitivitas yang ditetapkan. Error relatif tahunan sekitar 3\% dan error relative bulanan sekitar $10 \%[9]$.

Perancang dapat menyusun sistem pembangkit dari berbagai jenis sumber daya, baik sumber daya konvensional maupun yang terbaharukan. Proses simulasi pada HOMER dilakukan untuk mengetahui karakteristik atau performansi dari suatu sistem pembangkit

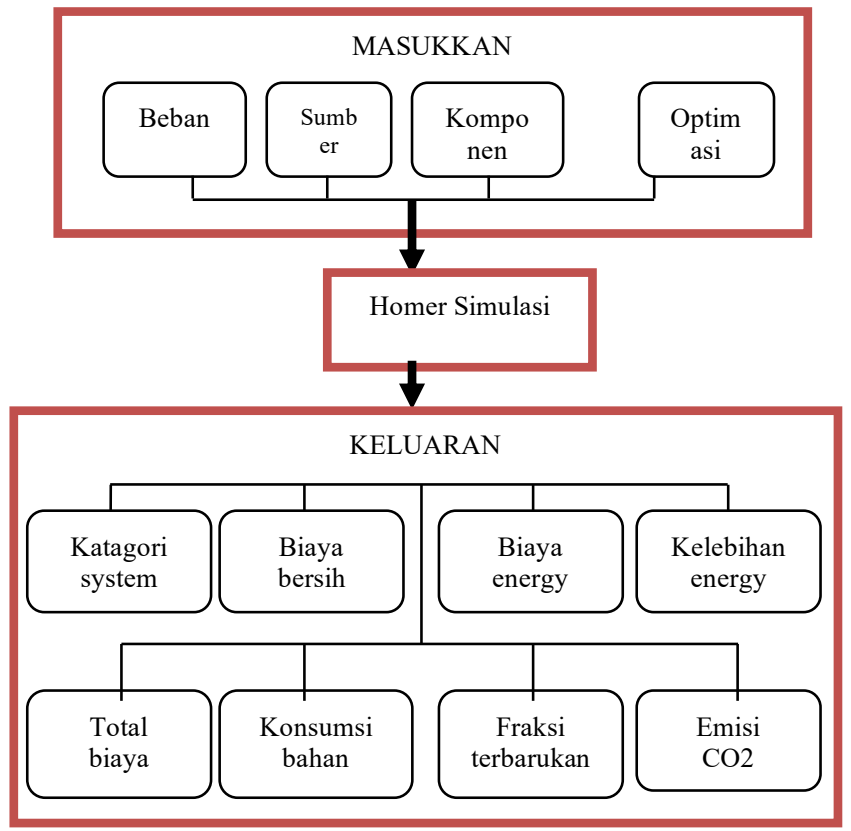

Gambar 1 Bagian Utama Arsitektur HOMER

\section{Hasil dan Pembahasan}

\subsection{Potensi Energi Sinar Matahari}

Kalimantan Barat yang berada tepat di bawah garis katulistiwa sehingga memiliki potensi menerima panas matahari yang besar. Penyinaran matahari global di Indonesia yaitu $1700-1950 \mathrm{KWh} / \mathrm{m}^{2} /$ tahun atau sama dengan 4,66-5,34 kWh/ m²/hari. Dari data Badan Meteorologi Klimotologi dan Geofisika Kabupaten Sambas yang terletah di Paloh dapat dilihat lama penyinaran matahari rata-rata dalam jam
Tabel 1 Data Penyinaran Matahari Bulan Februari 2018

\begin{tabular}{llll}
\hline Tanggal & $\begin{array}{l}\text { Lama } \\
\text { Penyinaran } \\
\text { (Jam) }\end{array}$ & Tanggal & $\begin{array}{l}\text { Lama } \\
\text { Penyinaran } \\
(\text { Jam })\end{array}$ \\
\hline $01 / 02 / 2018$ & 6,7 & $15 / 02 / 2018$ & 7,3 \\
$02 / 02 / 2018$ & 0,4 & $16 / 02 / 2018$ & 10,8 \\
$03 / 02 / 2018$ & 0,5 & $17 / 02 / 2018$ & 10,8 \\
$04 / 02 / 2018$ & 3 & $18 / 02 / 2018$ & 11 \\
$05 / 02 / 2018$ & 0 & $19 / 02 / 2018$ & 10,5 \\
$06 / 02 / 2018$ & 0,6 & $20 / 02 / 2018$ & 5 \\
$07 / 02 / 2018$ & 2 & $21 / 02 / 2018$ & 0 \\
$08 / 02 / 2018$ & 8,8 & $22 / 02 / 2018$ & 1,8 \\
$09 / 02 / 2018$ & 10,7 & $23 / 02 / 2018$ & 4 \\
$10 / 02 / 2018$ & 10,6 & $24 / 02 / 2018$ & 1,1 \\
$11 / 02 / 2018$ & 9,8 & $25 / 02 / 2018$ & 0,3 \\
$12 / 02 / 2018$ & 8,9 & $26 / 02 / 2018$ & 0,5 \\
$13 / 02 / 2018$ & 10,9 & $27 / 02 / 2018$ & 6,4 \\
$14 / 02 / 2018$ & 10,7 & $28 / 02 / 2018$ & 0 \\
\hline
\end{tabular}

Dari data yang diperoleh kita dapat melihat potensi yang dapat dihasilkan dari lama penyinaran matahari. BMKG Kabupaten Sambas sendiri melakukan pengukuran lama penyinaran matahari secara manual menggunakan Campbell Stokes. Campbell stokes terdiri dari bola pejal terbuat dari bahan gelas dengan diameter 4 inchi yang dipasangkan pada kedudukannya sehingga sinar matahari dapat difokuskan ke arah kartu pias dengan tajam. Kartu pias adalah kartu berskala sebagai alat perekam radiasi matahari.Kartu pias terbuat dari karton, berwarna biru gelap, dapat menyerap dan mudah tersinar oleh radiasi matahari, Pengamatan dilakukan dari jam $8.00 \mathrm{~s} / \mathrm{d} 16.00$ (selama 8 jam. Pias dibuat dari kertas khusus dengan tebal $0.4 \mathrm{~mm}$ dan hanya akan terbakar pada intensitas radiasi matahari $\geq 0.3 \mathrm{cal} / \mathrm{cm} 2$ menit atau $120 \mathrm{~W} / \mathrm{m} 2$.

Tabel 2 merupakan tabel pengukuran lama penyiran matahari Kabupaten Sambas yang sudah di rata-rata per jamnya setiap hari pada tahun 2018

Dari data di atas dapat diketahui potensi radiasi sinar matahari rata-rata perhari dapat menghasilkan 31,06 $\mathrm{MJ} / \mathrm{m} 2 / \mathrm{h}$. Jadi dapat diasumsikan $1 \mathrm{~m} 2$ dapat menghasilkan 83 watt. Melihat dari Tabel 3.3 Dusun Pelanjau RT 13 Sukadamai hanya memerlukan $330 \mathrm{kWh}$ per hari . Jika PLTS akan di pasang di Dusun Pelanjau kita hanya memerlukan $10 \mathrm{~m} \times 40 \mathrm{~m}=400 \mathrm{~m} 2$ luas tanah agar dapat menghasilkan $330 \mathrm{KWh}$

\subsection{Beban atau Daya yang Akan di Suplai}

Penggunaan listrik di dusun tetangga yang teraliri listrik PLN umumnya menggunakan peralatan listrik yang relatif sederhana. Lampu penerangan, televisi, pompa air, penanak nasi, setrika, kipas angin. Jika Dusun Pelanjau RT 13 Sukadamai yang terdiri 43 rumah memiliki listrik, maka dapat dibuat data beban 


\begin{tabular}{|c|c|c|c|c|c|c|c|c|c|c|c|c|}
\hline Bln & 1 & 2 & 3 & 4 & 5 & 6 & 7 & 8 & 9 & 10 & 11 & 12 \\
\hline $\mathrm{Tgl}$ & & & & & & & & & & & & \\
\hline 1 & 1,6 & 6,7 & 6,9 & 10,9 & 8,8 & 0,1 & 2,5 & 0 & 3,7 & 5,3 & 4,1 & 1,7 \\
\hline 2 & 3,2 & 0,4 & 0 & 10 & 11,6 & 2,1 & 3 & 0,9 & 0 & 3,1 & 0 & 5,7 \\
\hline 3 & 0,7 & 0,5 & 6,4 & 10 & 7 & 3,1 & 1,6 & 8,5 & 0 & 2,7 & 3,3 & 5,3 \\
\hline 4 & 5 & 3 & 7,2 & 0 & 10,9 & 8 & 2,8 & 9,9 & 4,7 & 3,4 & 0 & 7,5 \\
\hline 5 & 2,2 & 0 & 7,5 & 7,6 & 0 & 10,6 & 3 & 9,8 & 3,7 & 8,5 & 0 & 1,7 \\
\hline 6 & 1,2 & 0,6 & 3,9 & 6,5 & 10,8 & 10 & 3,5 & 9,7 & 5,5 & 0,1 & 8,8 & 7 \\
\hline 7 & 0 & 2 & 1,9 & 2,7 & 6,9 & 8,1 & 7,7 & 7,7 & 1,4 & 4,7 & 5 & 0 \\
\hline 8 & 2,3 & 8,8 & 0,7 & 9,3 & 0 & 8,6 & 8,2 & 8,7 & 5,7 & 3,1 & 0 & 2,5 \\
\hline 9 & 7,8 & 10,7 & 8,9 & 9,3 & 10,6 & 7,8 & 9,8 & 4 & 2,1 & 5,4 & 3,9 & 0,9 \\
\hline 10 & 1,9 & 10,6 & 3,2 & 0 & 10,8 & 6,6 & 8 & 6,3 & 5,4 & 2,6 & 4 & 8,8 \\
\hline 11 & 0 & 9,8 & 6,6 & 0 & 5,6 & 6,9 & 5,1 & 8 & 5,8 & 5,4 & 3,6 & 3,8 \\
\hline 12 & 2,9 & 8,9 & 6,8 & 1,9 & 9,2 & 4,2 & 1,7 & 9,1 & 0 & 0 & 8,9 & 3,4 \\
\hline 13 & 1 & 10,9 & 5,4 & 3,5 & 3,9 & 2,7 & 9,5 & $\begin{array}{l}11, \\
1\end{array}$ & 8,8 & 1,3 & 6,1 & 0,7 \\
\hline 14 & 0 & 10,7 & 0 & 0 & 6,3 & 6,7 & 9,3 & $\begin{array}{l}10 \\
1\end{array}$ & 8,8 & 0 & 3,7 & 6,2 \\
\hline 15 & 3,5 & 7,3 & 9,7 & 0 & 6,4 & 7,2 & 9,8 & 9,9 & 6,4 & 0 & 1,8 & 2,9 \\
\hline 16 & 3,6 & 10,8 & 0 & 0,2 & 4,4 & 8,4 & 10,6 & 9,6 & $\begin{array}{l}10 \\
4\end{array}$ & 4,2 & 3 & 6,2 \\
\hline 17 & 6,3 & 10,8 & 7,1 & 0 & 0,5 & 9,8 & 10,6 & 7 & 7,6 & 1,8 & 8 & 6,1 \\
\hline 18 & 0 & 11 & 5,4 & 6,4 & 6,9 & 10,3 & 9,6 & 8,9 & 9 & 2,1 & 0,5 & 4,1 \\
\hline 19 & 2,6 & 10,5 & 5,2 & 0 & 5,9 & 10,7 & 7,9 & $\begin{array}{l}10 \\
1\end{array}$ & 0,4 & 0 & 9 & 5,4 \\
\hline 20 & 6,3 & 5 & 8,1 & 7,6 & 1,9 & 4,4 & 9,3 & 7,7 & 0 & 1,3 & 4,5 & 7,5 \\
\hline 21 & 3,5 & 0 & 5,3 & 9,4 & 2,7 & 10,2 & 0 & 4,7 & 4,4 & 3,5 & 4,6 & 1,4 \\
\hline 22 & 6,3 & 1,8 & 4,2 & 2,6 & 10 & 0,5 & 1,7 & 3,3 & 4,9 & 7 & 4 & 2,8 \\
\hline 23 & 7,8 & 4 & 9,4 & 9,8 & 8,7 & 6,4 & 1,3 & 9,3 & 3,4 & 8,8 & 7,7 & 5,3 \\
\hline 24 & 8,4 & 1,1 & 5,9 & 0 & 0 & 3,4 & 9,9 & 0 & 6,3 & 6,7 & 6,6 & 4,8 \\
\hline 25 & 4 & 0,3 & 0 & 7,5 & 2,8 & 3 & 9,4 & 0 & 2,6 & 5 & 1,9 & 9,9 \\
\hline 26 & 5,2 & 0,5 & 2,4 & 3,5 & 3,2 & 1,3 & 1,4 & 8,9 & 1,1 & 1,4 & 7,4 & 9,1 \\
\hline 27 & 0 & 6,4 & 7,6 & 8,8 & 1,9 & 8 & 7 & 6,4 & 5,1 & 1,5 & 6,6 & 3,8 \\
\hline 28 & 5,5 & 0 & 2,8 & 10,6 & 8,4 & 7,2 & 9,5 & 1,4 & 7,1 & 0 & 6,8 & 0 \\
\hline 29 & 1,7 & 0 & 4,2 & 8,7 & 1,6 & 5,1 & 2,1 & 3,7 & 4,7 & 8,3 & 6,8 & 5,5 \\
\hline 30 & 5,1 & 0 & 9,3 & 7,9 & 7,3 & 4,7 & 8,6 & 0 & 2,1 & $\begin{array}{l}10 \\
7\end{array}$ & 1,4 & 6,7 \\
\hline 31 & 0 & 0 & 9,4 & 0 & 8,5 & 0 & 4,1 & 3,7 & 0 & 9,1 & 0 & 6,1 \\
\hline $\begin{array}{l}\text { Rata- } \\
\text { Rata }\end{array}$ & 3,3 & 5,5 & 5,2 & 5,2 & 5,9 & 6,2 & 6,1 & 6,4 & 4,4 & 3,8 & 4,4 & 4,6 \\
\hline
\end{tabular}


Tabel 3 Hasil konversi lama penyinaran matahari ke $\mathrm{MJ} / \mathrm{m} 2 / \mathrm{h}$

\begin{tabular}{|c|c|c|c|c|c|c|c|c|c|c|c|c|}
\hline $\begin{array}{l}\text { Bln } \\
\text { Tgl }\end{array}$ & 1 & 2 & 3 & 4 & 5 & 6 & 7 & 8 & 9 & 10 & 11 & 12 \\
\hline 1 & 1,6 & 6,7 & 6,9 & 10,9 & 8,8 & 0,1 & 2,5 & 0 & 3,7 & 5,3 & 4,1 & 1,7 \\
\hline 2 & 3,2 & 0,4 & 0 & 10 & 11,6 & 2,1 & 3 & 0,9 & 0 & 3,1 & 0 & 5,7 \\
\hline 3 & 0,7 & 0,5 & 6,4 & 10 & 7 & 3,1 & 1,6 & 8,5 & 0 & 2,7 & 3,3 & 5,3 \\
\hline 4 & 5 & 3 & 7,2 & 0 & 10,9 & 8 & 2,8 & 9,9 & 4,7 & 3,4 & 0 & 7,5 \\
\hline 5 & 2,2 & 0 & 7,5 & 7,6 & 0 & 10,6 & 3 & 9,8 & 3,7 & 8,5 & 0 & 1,7 \\
\hline 6 & 1,2 & 0,6 & 3,9 & 6,5 & 10,8 & 10 & 3,5 & 9,7 & 5,5 & 0,1 & 8,8 & 7 \\
\hline 7 & 0 & 2 & 1,9 & 2,7 & 6,9 & 8,1 & 7,7 & 7,7 & 1,4 & 4,7 & 5 & 0 \\
\hline 8 & 2,3 & 8,8 & 0,7 & 9,3 & 0 & 8,6 & 8,2 & 8,7 & 5,7 & 3,1 & 0 & 2,5 \\
\hline 9 & 7,8 & 10,7 & 8,9 & 9,3 & 10,6 & 7,8 & 9,8 & 4 & 2,1 & 5,4 & 3,9 & 0,9 \\
\hline 10 & 1,9 & 10,6 & 3,2 & 0 & 10,8 & 6,6 & 8 & 6,3 & 5,4 & 2,6 & 4 & 8,8 \\
\hline 11 & 0 & 9,8 & 6,6 & 0 & 5,6 & 6,9 & 5,1 & 8 & 5,8 & 5,4 & 3,6 & 3,8 \\
\hline 12 & 2,9 & 8,9 & 6,8 & 1,9 & 9,2 & 4,2 & 1,7 & 9,1 & 0 & 0 & 8,9 & 3,4 \\
\hline 13 & 1 & 10,9 & 5,4 & 3,5 & 3,9 & 2,7 & 9,5 & 11,1 & 8,8 & 1,3 & 6,1 & 0,7 \\
\hline 14 & 0 & 10,7 & 0 & 0 & 6,3 & 6,7 & 9,3 & 10,1 & 8,8 & 0 & 3,7 & 6,2 \\
\hline 15 & 3,5 & 7,3 & 9,7 & 0 & 6,4 & 7,2 & 9,8 & 9,9 & 6,4 & 0 & 1,8 & 2,9 \\
\hline 16 & 3,6 & 10,8 & 0 & 0,2 & 4,4 & 8,4 & 10,6 & 9,6 & 10,4 & 4,2 & 3 & 6,2 \\
\hline 17 & 6,3 & 10,8 & 7,1 & 0 & 0,5 & 9,8 & 10,6 & 7 & 7,6 & 1,8 & 8 & 6,1 \\
\hline 18 & 0 & 11 & 5,4 & 6,4 & 6,9 & 10,3 & 9,6 & 8,9 & 9 & 2,1 & 0,5 & 4,1 \\
\hline 19 & 2,6 & 10,5 & 5,2 & 0 & 5,9 & 10,7 & 7,9 & 10,1 & 0,4 & 0 & 9 & 5,4 \\
\hline 20 & 6,3 & 5 & 8,1 & 7,6 & 1,9 & 4,4 & 9,3 & 7,7 & 0 & 1,3 & 4,5 & 7,5 \\
\hline 21 & 3,5 & 0 & 5,3 & 9,4 & 2,7 & 10,2 & 0 & 4,7 & 4,4 & 3,5 & 4,6 & 1,4 \\
\hline 22 & 6,3 & 1,8 & 4,2 & 2,6 & 10 & 0,5 & 1,7 & 3,3 & 4,9 & 7 & 4 & 2,8 \\
\hline 23 & 7,8 & 4 & 9,4 & 9,8 & 8,7 & 6,4 & 1,3 & 9,3 & 3,4 & 8,8 & 7,7 & 5,3 \\
\hline 24 & 8,4 & 1,1 & 5,9 & 0 & 0 & 3,4 & 9,9 & 0 & 6,3 & 6,7 & 6,6 & 4,8 \\
\hline 25 & 4 & 0,3 & 0 & 7,5 & 2,8 & 3 & 9,4 & 0 & 2,6 & 5 & 1,9 & 9,9 \\
\hline 26 & 5,2 & 0,5 & 2,4 & 3,5 & 3,2 & 1,3 & 1,4 & 8,9 & 1,1 & 1,4 & 7,4 & 9,1 \\
\hline 27 & 0 & 6,4 & 7,6 & 8,8 & 1,9 & 8 & 7 & 6,4 & 5,1 & 1,5 & 6,6 & 3,8 \\
\hline 28 & 5,5 & 0 & 2,8 & 10,6 & 8,4 & 7,2 & 9,5 & 1,4 & 7,1 & 0 & 6,8 & 0 \\
\hline 29 & 1,7 & 0 & 4,2 & 8,7 & 1,6 & 5,1 & 2,1 & 3,7 & 4,7 & 8,3 & 6,8 & 5,5 \\
\hline 30 & 5,1 & 0 & 9,3 & 7,9 & 7,3 & 4,7 & 8,6 & 0 & 2,1 & 10,7 & 1,4 & 6,7 \\
\hline 31 & 0 & 0 & 9,4 & 0 & 8,5 & 0 & 4,1 & 3,7 & 0 & 9,1 & 0 & 6,1 \\
\hline $\begin{array}{l}\text { Rata- } \\
\text { Rata }\end{array}$ & 3,3 & 5,5 & 5,2 & 5,2 & 5,9 & 6,2 & 6,1 & 6,4 & 4,4 & 3,8 & 4,4 & 4,6 \\
\hline
\end{tabular}

dan pola oprasional sehari-hari yang mirip dengan dusun tetangga

Pola penggunaan peralatan listrik ini digunakan sebagai acuan untuk menghasilkan kapasitas energi listrik yang digunakan setiap jamnya dalam satu hari serta besar energi listrik per harinya. Dibawah ini menunjukan profil 
beban dengan beban punjak $25 \mathrm{~kW}$. Penjelasan mengenai rata-rata penggunaan energi listrik yang digunakan setiap jamnya dalam satu hari di Dusun pelanjau RT 13 Sukadamai terdapat pada Tabel 4

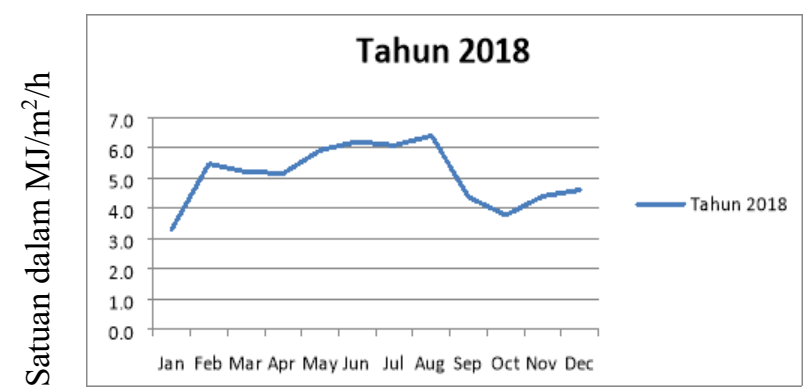

Gambar2 Grafik Lama Penyinaran matahari

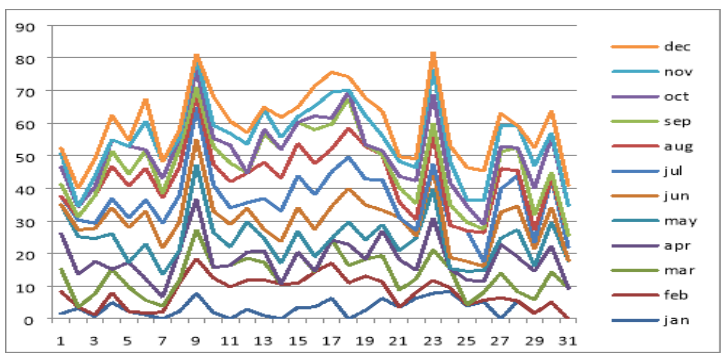

Gambar 3 Grafik Lama Penyinaran Matahari Dalam Satu Tahun

Tabel 4 Rata Rata Beban Listri Harian

\begin{tabular}{|c|c|c|c|}
\hline Jam & $\begin{array}{c}\text { Rata - Rata } \\
(\mathrm{kWh})\end{array}$ & Jam & $\begin{array}{c}\text { Rata - } \\
\text { Rata } \\
(\mathrm{kWh})\end{array}$ \\
\hline $\begin{array}{c}00: 00- \\
01: 00\end{array}$ & 5.50 & $\begin{array}{c}12: 00- \\
13: 00\end{array}$ & 15.50 \\
\hline $\begin{array}{c}01: 00- \\
02: 00\end{array}$ & 5.50 & $\begin{array}{c}13: 00- \\
14: 00\end{array}$ & 18.16 \\
\hline $\begin{array}{c}02: 00- \\
03: 00\end{array}$ & 5.50 & $\begin{array}{c}14: 00- \\
15: 00\end{array}$ & 10.15 \\
\hline $\begin{array}{c}\text { 03:00 - } \\
\text { 04:00 }\end{array}$ & 5.50 & $\begin{array}{c}15: 00- \\
16: 00\end{array}$ & 10.28 \\
\hline $\begin{array}{c}\text { 04:00 - } \\
05: 00\end{array}$ & 10.15 & $\begin{array}{c}16: 00- \\
17: 00\end{array}$ & 10.28 \\
\hline $\begin{array}{c}05: 00- \\
06: 00\end{array}$ & 23.10 & $\begin{array}{c}17: 00- \\
18: 00\end{array}$ & 24.32 \\
\hline $\begin{array}{c}\text { 06:00 - } \\
07: 00\end{array}$ & 24.50 & $\begin{array}{c}18: 00- \\
19: 00\end{array}$ & 24.80 \\
\hline $\begin{array}{c}\text { 07:00 - } \\
08: 00\end{array}$ & 20.05 & $\begin{array}{l}\text { 19:00 - } \\
20: 00\end{array}$ & 22.52 \\
\hline $8: 00-09: 00$ & 20.07 & $\begin{array}{c}20: 00- \\
21: 00\end{array}$ & 18.16 \\
\hline $\begin{array}{c}\text { 09:00 - } \\
\text { 10:00 }\end{array}$ & 10.25 & $\begin{array}{c}21: 00- \\
22: 00\end{array}$ & 18.52 \\
\hline $\begin{array}{c}10: 00- \\
11: 00\end{array}$ & 7.05 & $\begin{array}{c}22: 00- \\
23: 00\end{array}$ & 10.15 \\
\hline $\begin{array}{c}11: 00- \\
12: 00\end{array}$ & 7.05 & $\begin{array}{c}23: 00- \\
00: 00\end{array}$ & 5.50 \\
\hline
\end{tabular}

\subsection{Analisis Optimasi HOMER}

Perancangan system menggunakan software Homer. Komponen sistem yang digunakan terdiri dari PV Array, Biomassa, Concerter, Baterai dan Grid

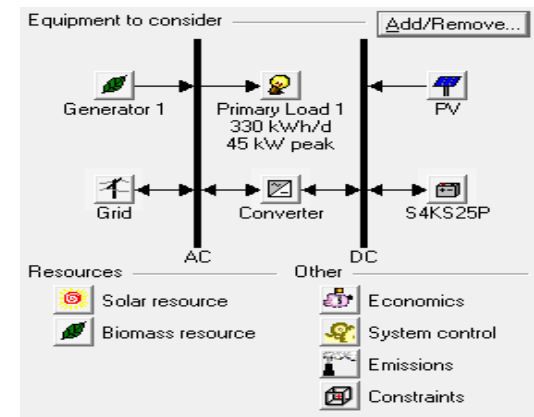

Gambar 4 Peracangan Konfigurasi Homer Energi

Homer telah melakukan simulasi terhadap lebih dari 192 konfigurasi sistem. Konfigurasi terbaik adalah konfigurasi yang memiliki Net Present Cost (NPC) paling kecil. NPC merupakan nilai saat ini dari semua biaya yang muncul selama masa pakai dikurangi semua pendapatan yang diperoleh selama masa pakai. Sedangkan Cost of Energy (COE) merupakan rata-rata per kWh dari energi listrik yang dihasilkan oleh sistem. Berdasarkan hasil simulai rata-rata energi listrik perhari yang diperlukan adalah sebesar $330 \mathrm{kWh} /$ hari, rata-rata beban listrik sebesar $13,7 \mathrm{~kW}$ dan beban puncak yang mungkin terjadi adalah sebesar $44.6 \mathrm{~kW}$ dalan satu tahun, sehingga faktor beban yang perbandingan antara rata-rata beban listrik dan beban puncak adalah 0.308

\subsection{Hasil Pembangkit Sistem dengan Biomassa}

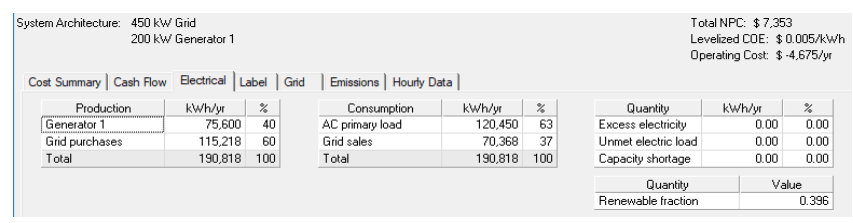

Gambar 5 Daya yang Dibangkitkan Konfigurasi Biomassa

Pada gambar 5 tampak bahwa daya yang dihasilkan pembangkit sebesar $190.818 \mathrm{kWh} /$ tahun, yang tersuplai dari Generator limbah sekam padi dan jerami yang dihasilkan yaitu sebesar $75.600 \mathrm{kWh} /$ tahun $(40 \%)$ dan grid PLN sebesar $115.218 \mathrm{kWh} /$ tahun (60\%). Dengan konsumsi listrik sebesar $120.450 \mathrm{kWh} / \operatorname{tahun}(63 \%)$ dan sisanya dapat dijual ke PLN sebesar $70.368 \mathrm{kWh} /$ tahun (37\%). Sistem ini tidak menghasilkan energi sisa. Semua energi listrik yang dihasilkan digunakan oleh beban dan dijual ke Grid (PLN). Dari system diatas juga terlihat bahwa tidak ada beban listrik yang tidak terpenuhi dan tidak pernah terjadi kekurangan kapasitas litrik dalam satu tahun 


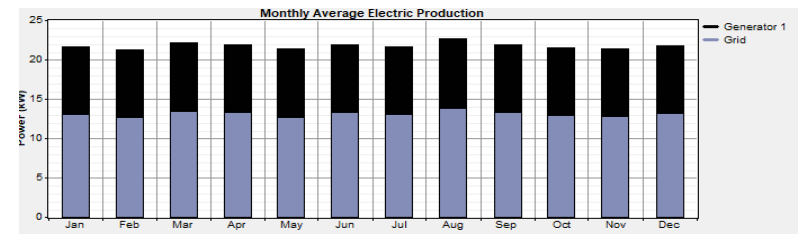

Gambar 6 Produksi Listrik Perbulan dengan Biomassa

Dari Gambar 6 produksi listrik per bulan menunjukkan bahwa dalam satu tahun relatif stabil. Hal ini dikarenakan pembangkit utama listrik adalah generator limbah sekam padi dan jerami yang dihasilkan (warna hitam) dan yang paling bawah adalah grid suplay dari PLN (warna biru)

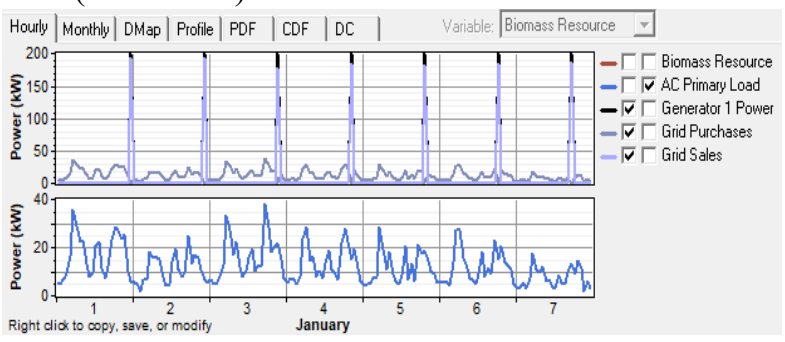

Gambar 7 Grafik Produksi dan Konsumsi Listrik

Pada gambar di atas terdapat dua gambar kolom, kolom pertama merupakan kolom dimana listrik menggunakan pembangkit generator, listrik yang dibeli dari PLN, dan listrik yang dijual ke PLN. Sedangkan kolom kedua merupakan grafik listrik yang yang dikonsumsi oleh Dusun Pelanjau RT 13 Sukadamai secara real time. Pada kolom pertama (atas), garis hitam adalah listrik yang dibangkitkan dengan generator dari limbah sekam padi dan jerami, dari gambar dapat dilihat bahwa limbah yang dihasilkan dapat memenuhi kebutuhan listrik di Dusun Pelanjau RT 13 Sukadamai, sedangkan dari PLN untuk mencatu penerangan dusun ketika malam hari, sehingga grafik dari PLN yang berwarna biru tua di malam hari tidak banyak. Grafik pada kolom kedua (bawah) adalah grafik konsumsi listrik di Dusun Pelanjau RT 13 Sukadamai yang harus dipenuhi.

Energi listrik yang dibangkitkan oleh generator dapat mencukupi, sehingga dapat dijual kembali ke Tabel 6 Hasil konfigurasi sistem paling optimal Homer

PLN. Grafik penjualan energi listrik ditunjukkan grafik Energi

berwarna biru muda pada kolom atas. Dengan adanya limbah sekam padi dan jerami Dusun Pelanjau RT 13 Sukadamai telah mengaplikasikan renewable energy. Keunggulan dari renewable energy adalah pasokah (KW) energi yang akan terus selalu ada dan emisi gas buaAattery yang ramah lingkungan. (Units) Pada Gambar 7 menunjukkan bahwa konfigurasi antargnverter Generator dan PLN memiliki renewable fraction yang dihasilkan adalah 0.396 , artinya $39,6 \%$ pembangkit $(\mathrm{KW})$ energy pada Dusun Pelanjau RT 13 Sukadama1 menggunakan energi terbarukan. Renewable fractienpital (\$) yaitu rasio dari pembangkit energi terbarukan Operating Cost (\$/thn)
3.4 Analisa Ekonomi Sistem Teroptimal Bimassa

Dari data-data di atas dengan demikian secara rata-rata dengan adanya limbah energi terbarukan dari sekam padi dan jerami Dusun Pelanjau RT 13 Sukadamai bisa menjual listrik ke PLN sebesar $70.368 \mathrm{KWh} /$ tahun dan membeli listrik dari PLN untuk catu daya sebesar 115.218 KWh/tahun. Dengan harga jual listrik ke PLN sebesar US\$ 0,25/KWh dan harga beli ke PLN sebesar \$ $0,104 / \mathrm{KWh}$ nya, maka bisa dipastikan konfigurasi Generator dan PLN akan surplus dan menguntungkan

Tabel 5 Data Pembelian dan Penjualan Listrik

\begin{tabular}{|c|c|c|c|c|c|c|}
\hline \multirow{3}{*}{ Month } & Energy & Energy & Net & Peak & Energy & Demand \\
\hline & Purchased & Sold & Purchases & Demand & Charge & Charge \\
\hline & [kWh] & [kWh] & [kWh] & {$[\mathrm{kW})$} & [\$] & [\$] \\
\hline Jan & 9.698 & 5,959 & 3,739 & 40 & -481 & 0 \\
\hline Feb & 8,534 & 5,409 & 3,125 & 42 & .465 & 0 \\
\hline Mar & 10,063 & 5,938 & 4,125 & 41 & -438 & 0 \\
\hline Apr & 9.573 & 5,785 & 3,788 & 41 & -451 & 0 \\
\hline May & 9,490 & 5.979 & 3,510 & 38 & .508 & 0 \\
\hline Jun & 9,577 & 5,766 & 3,811 & 40 & -446 & 0 \\
\hline Jul & 9,686 & 5,954 & 3,732 & 40 & -481 & 0 \\
\hline Aug & 10,294 & 6,138 & 4,156 & 38 & .464 & 0 \\
\hline Sep & 9.624 & 5,756 & 3,867 & 39 & .438 & 0 \\
\hline Oct & 9.630 & 5,919 & 3.711 & 39 & .478 & 0 \\
\hline Nov & 9,256 & 5,793 & 3,463 & 43 & .486 & 0 \\
\hline Dec & 9,794 & 5.973 & 3,822 & 39 & -475 & 0 \\
\hline Annual & 115,218 & 70,368 & 44,850 & 43 & $-5,609$ & 0 \\
\hline
\end{tabular}

\subsection{Konsfigurasi Sistem dengan PV dan Biomassa}

Desain sistem pembangkit dengan menggunakan PV dan energi biomassa yang terbaik untuk Dusun Pelanjau RT

13 Sukadamai adalah dengan kombinasi di blog kedua.

\begin{tabular}{|c|c|c|c|c|c|c|c|c|c|c|c|c|}
\hline \multicolumn{13}{|c|}{ Double click on a system below for simulation results. } \\
\hline 1甲出因 & & $\begin{array}{l}\text { Label } \\
\text { (kW) }\end{array}$ & S4KS25P & $\begin{array}{l}\text { Conv. } \\
\text { (kW) }\end{array}$ & $\begin{array}{l}\text { Gind } \\
(\mathrm{kW})\end{array}$ & $\begin{array}{l}\text { Intitial } \\
\text { Capital }\end{array}$ & $\begin{array}{l}\text { Operating } \\
\text { Cost }(s / y) \text {. }\end{array}$ & $\begin{array}{l}\text { Total } \\
\text { NPC }\end{array}$ & $\begin{array}{c}\text { COE } \\
(S / k W h)\end{array}$ & \begin{tabular}{|l|} 
Ren. \\
Frac.
\end{tabular} & \begin{tabular}{|c|} 
Biomass \\
$(t)$
\end{tabular} & $\begin{array}{l}\text { Label } \\
\text { (hrs) }\end{array}$ \\
\hline & & 200 & & & 450 & $\$ 67,120$ & $-4,675$ & $\$ 7,353$ & 0.005 & 0.40 & 147 & 378 \\
\hline & 30 & 200 & 10 & 750 & 450 & $\$ 138,700$ & $\cdot 1,755$ & $\$ 116,265$ & 0.076 & 0.57 & 147 & 378 \\
\hline & 30 & 200 & & 750 & 450 & $\$ 135,520$ & $.1,430$ & $\$ 117,241$ & 0.076 & 0.61 & 147 & 378 \\
\hline & & & & & 450 & so & 12,527 & $\$ 160,134$ & 0.104 & 0.00 & & \\
\hline 2 & & 200 & 10 & 750 & 450 & $\$ 136,300$ & 5,437 & $\$ 205,802$ & 0.134 & 0.37 & 147 & 378 \\
\hline & 30 & & 10 & 750 & 450 & $\$ 71,580$ & 15,735 & $\$ 272730$ & 0.177 & 0.34 & & \\
\hline$T$ & 30 & & & 750 & 450 & $\$ 68,400$ & 16,002 & $\$ 272,955$ & 0.177 & 0.38 & & \\
\hline 国 & & & 10 & 750 & 450 & $\$ 69,180$ & 22,954 & $\$ 362,613$ & 0.236 & 0.00 & & \\
\hline
\end{tabular}

Gambar 8 Hasil Kalkulasi Konfigurasi Homer Energi

Gambar diatas menunjukan hasil optimasi dari parameter-parameter komponen yang di input ke dalan Homer. Dari konfigurasi sistem dapat kita lihat di blog kedua dengan spesifikasi $30 \mathrm{KW}$ PV, $750 \mathrm{KW}$ converter, 5 unit baterai dan terhubung ke grid $450 \mathrm{KW}$.

Konfigurasi Keterangan




\begin{tabular}{lcl} 
NPC $(\$)$ & $\$ 116.265$ & $\begin{array}{l}\text { dana pengeluaran dikurangi surplus } \\
\text { sebesar } \$ 116.265 \\
\text { rata-rata listrik yang dihasilkan sebesar } \\
\mathrm{COE}\end{array}$ \\
$(\$ / \mathrm{KW})$ & 0.076 & $\$ 0,076 / \mathrm{KW}$ \\
\hline
\end{tabular}

\subsection{Hasil Pembangkit Sistem dengan PV dan Biomassa}

\begin{tabular}{|c|c|c|c|c|c|c|c|c|c|c|}
\hline System Architecture: & $200 \mathrm{~kW}$ Generator 1 & $450 \mathrm{~kW}$ Gind & & $\begin{array}{l}\text { unett } \\
\text { kWW/n } \\
\text { kW }\end{array}$ & $\begin{array}{l}\text { AKS25P } \\
\text { verter } \\
\text { ectifier }\end{array}$ & Charging & & & $\begin{array}{l}\text { ANPC: } \$ 116 \\
\text { elized COE: } \\
\text { ating Cost }\end{array}$ & $\begin{array}{l}.265 \\
0.076 / \mathrm{kWh} \\
.1,75 / \mathrm{gr}\end{array}$ \\
\hline Cost Summay $\mid$ & Cash Flow & Eectical |p & & abel & $\mid$ Battery $\mid$ Converter & Gin | Enissi & $n=\mid r$ & & & \\
\hline \multicolumn{2}{|c|}{ Production } & kwh/y & $\%$ & & Consumption & kWhyn & $\%$ & Quantily & kWh/y & $\%$ \\
\hline \multicolumn{2}{|l|}{ PV aray } & 53,337 & 24 & & AC p pimary lood & 120,450 & 56 & Excess electricty & 0.00102 & 0.00 \\
\hline \multicolumn{2}{|l|}{ Generator 1} & 75,600 & 33 & & Gird sales & 94,917 & 44 & Unmet electric load & 0.00 & 0.00 \\
\hline \multicolumn{2}{|l|}{ Gind puchases } & 97,993 & 43 & & Total & 215,366 & 100 & Capacily shotiage & 0.00 & 0.00 \\
\hline \multirow[t]{2}{*}{ Total } & & 226,931 & 100 & & & & & Quanity & & She \\
\hline & & & & & & & & Renewable fraction & & 0.568 \\
\hline
\end{tabular}

Gambar 9 Daya yang Dibangkitkan Konfigurasi PV dan Biomassa

Pada gambar di atas daya yang dihasilkan pembangkit PV dn Biomassa sebesar 226.931 kWh/tahun, yang tersuplay dari PV Array 53.337 (24\%), Generator limbah sekam padi dan jerami yang dihasilkan yaitu sebesar $76.600 \mathrm{kWh} /$ tahun $(33 \%)$ dan grid PLN sebesar $97.993 \mathrm{kWh} /$ tahun $(43 \%)$. Dengan konsumsi listrik sebesar $120.450 \mathrm{kWh} /$ tahun $(56 \%)$ dan sisanya dapat dijual ke PLN sebesar $94.917 \mathrm{kWh} /$ tahun (44\%). Sistem ini tidak menghasilkan energi sisa. Semua energi listrik yang dihasilkan digunakan oleh beban dan dijula ke Grid (PLN).

Dari sistem diatas juga terlihat bahwa tidak ada beban listrik yang tidak terpenuhi dan tidak pernah terjadi kekurangan kapasitas litrik dalam satu tahun. Konsfigurasi sitem PV dan biomassa dapat menghasilkan listrik lebih banyak dibandingkan konfigurasi biomassa. Hal itu dikarenakan PV dapat membantu menghasilkan listrik untuk Dusun Pelanjau RT 13 Sukadamai sehingga dusun tersebut hanya membeli listrik PLN lebih sedikit yaitu hanya $43 \%$ nilai ini lebih kecil dari pada hanya menggunakan konsfigurasi sitem biomassa.

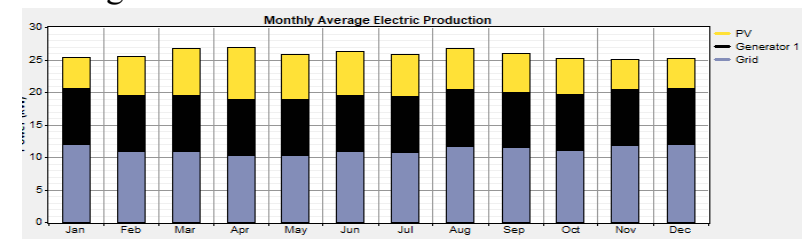

Gambar 10 Produksi Listrik Perbulan dengan PV dan Biomassa

Dari Gambar 10 menunjukkan bahwa dalam satu tahun relatif stabil. Dapat dilihat pada bagan bahwasannya ketika musim kemarau listrik yang dibangkitkan akan lebih besar dari pada ketika musim penghujan. Hal ini dapat dilihat pada bagan bulan Maret-Juni. Ketika musim penghujan akan lebih sering terjadi penurunan intensitas radiasi matahari yang disebabkan karena sering adanya mendung maupun hujan. Hal ini dapat dilihat pada gambar dari bulan November-Januari

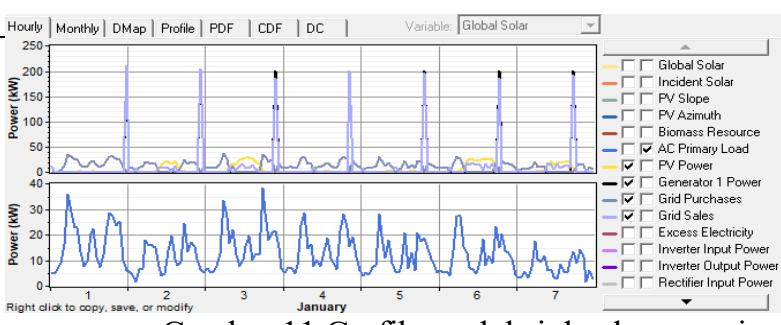

Gambar 11 Grafik produksi dan konsums listrik

Perbedaan grafik 11 dan 10 adalah terletak pertama (atas), garis hitam adalah listrik yang dibangkitkan dengan generator dari limbah sekam padi dan jerami, sedangkan garis kuning adalah listrik yang di bangkitkan dengan PV. Dari grafik dapat dilihat bahwa PLTS yang mengaplikasikan batrei dapat menyimpan energi listrik yang di hasilkan untuk kebutuhan dimalam hari.

Dengan adanya limbah sekam padi dan jerami serta energi surya sebagai pembangkit, Dusun Pelanjau RT 13 Sukadamai telah mengaplikasikan renewable energy. Pada Tabel 4.10 menunjukkan bahwa konfigurasi antara PLTS, Generator dan PLN memiliki renewable fraction yang dihasilkan adalah 0.568, artinya 56,8\% pembangkit energy pada Dusun Pelanjau RT 13 Sukadamai menggunakan energi terbarukan. Nilai ini lebih besar dari pada konsfigurasi sistem biomassa karena energi yang dihasilkan oleh matahari tidak memliki polutan.

Tabel 7 Polutan yang Dihasilkan

\begin{tabular}{|l|r|}
\multicolumn{1}{|c|}{ Pollutant } & Emissions [kg/yr] \\
\hline Carbon dioxide & 1.970 \\
\hline Carbon monoxide & 0.955 \\
\hline Unbur........ & 0.106 \\
\hline Particulate matter & 0.072 \\
\hline Sulfur dioxide & 8.43 \\
\hline Nitrogen oxides & 12.6 \\
\hline
\end{tabular}

3.7 Analisa Ekonomi Sistem Teroptimal PV dan Bimassa

Dari data-data di atas dengan demikian secara rata-rata dengan adanya limbah energi terbarukan dari sekam padi dan jerami serta energi matahari Dusun Pelanjau RT 13 Sukadamai bisa menjual listrik ke PLN sebesar 94.917 KWh/tahun dan membeli listrik dari PLN untuk catu daya sebesar $97.993 \mathrm{KWh} /$ tahun. Hal ini dapat dinyatakan seimbang, maka bisa dipastikan konfigurasi PLTS, Generator dan PLN akan surplus dan menguntungkan. Berikut adalah persamaannya :

$$
\begin{aligned}
& \text { Jual ke PLN }=94.917 \frac{\mathrm{KWh}}{\mathrm{thn}} \times \$ 0,25 / \mathrm{KWh} \\
& =\mathbf{\$} \mathbf{2 3 . 7 2 9 / \text { thn }} \\
& \text { Beli dari PLN }=97.993 \frac{\mathrm{KWh}}{\mathrm{thn}} \times \$ 0,104 / \mathrm{KWh} \\
& =\$ \mathbf{1 0 . 1 9 1 / \text { thn }}
\end{aligned}
$$$$
\text { Surplus }=\$ 23.729 / \text { thn }-\$ 10.191 / \text { thn }
$$ 
$=\$ 13.538 /$ thn

Secara perhitungan setiap tahun energi dari limbah sekam padi dan jerami serta tenaga surya surplus sebesar \$ 13.538. Tabel 4.11 akan menjabarkan rincian keuangan masuk dan keluar sehingga didapatkan surplus setiap tahunnya.

Tabel 8 Data Pembelian dan Penjualan Listrik

\begin{tabular}{|c|c|c|c|c|c|c|}
\hline \multirow{3}{*}{ Month } & Energy & Energy & Net & Peak & Energy & Demand \\
\hline & Purchased & Sold & Purchases & Demand & Charge & Charge \\
\hline & [kWh] & [kWh] & [kWh] & {$[\mathrm{kW}]$} & (\$) & [\$] \\
\hline Jan & 8.887 & 7.904 & 983 & 42 & -1.052 & 0 \\
\hline Feb & 7,305 & 7,352 & -47 & 44 & $-1,078$ & 0 \\
\hline Mar & 8,107 & 8,307 & .200 & 42 & -1.234 & 0 \\
\hline Apr & 7,388 & 8.288 & .901 & 44 & $-1,304$ & 0 \\
\hline May & 7.631 & 8.327 & -696 & 41 & $-1,288$ & 0 \\
\hline Jun & 7,886 & 7.893 & .7 & 43 & -1.153 & 0 \\
\hline Jul & 8.031 & 8.034 & -3 & 44 & $-1,173$ & 0 \\
\hline Aug & 8.679 & 8.198 & 482 & 41 & $-1,147$ & 0 \\
\hline Sep & 8.254 & 7.692 & 561 & 42 & $-1,065$ & 0 \\
\hline Oct & 8,284 & 7,703 & 580 & 41 & $-1,064$ & 0 \\
\hline Nov & 8,558 & 7,518 & 1,040 & 46 & -989 & 0 \\
\hline Dec & 8,984 & 7.700 & 1.284 & 42 & -991 & 0 \\
\hline Annual & 97,993 & 94.917 & 3.077 & 46 & $-13,538$ & 0 \\
\hline
\end{tabular}

Payback period $=\frac{\$ 138.700}{\$ 13.538 / \text { thn }}=10,24$ tahun

Konfigurasi system pembangkit PLTS dan Nilai ini lebih besar dari pembangkit biomas sendiri setelahnya sampai dengan tahun ke 25 merupakan dikarenakan biaya yang dikeluarkan lebih besar untuk keuntungan bagi Dusun yang terus bisa menjual listrik mendesin PV dan membeli batrei. Tetapi payback period ke PLN sebesar \$ 94.917//tahun

yang di hasilkan lebih kecil karena dengan system konfigurasi PLTS dan biomassa dapat menghasilkan energy listrik yang lebih banyak. Sehingga surplus lebih besar. Jadi dalam kurun waktu selama 10.24 tahun ini dibandingkan dengan sistem grid yang telah lama ada sudah bisa mengembalikan modal yang dikeluarkan. dan terbukti mampu mencatu kebutuhan energi listrik Akan tetapi perlu diingat bahwasannya setiap 5 tahun pelanggan. Pada Hasil konsfigurasi HOMER diketahui sekali, harus ada peremajaan converter sebesar $\$$ nilai dari operating cost untuk grid biomassa adalah 66.000,00. Dalam jangka waktu 25 umur sistem sebesar \$-4.675 dan operating cost untuk grid PV dan pembangkit ini berarti butuh 5 kali peremajaan biomassa adalah sebesar \$-1.755. Nilai ini mengartikan converter.

$$
\begin{gathered}
\text { Payback period all }=\frac{\$ 138.700+(\$ 13.200)}{\$ 13.538 / \text { thn }} \\
=\frac{\$ 151.900}{\$ 13.538 / \text { thn }}=11,22 \text { tahun }
\end{gathered}
$$

Jadi melalui perhitungan payback keseluruhan akan mengembalikan modal dalam kurun waktu selama 11,22 tahun. Hal ini dikarenakan adanya penambahan biaya peremajaan.

Tabel 9 Nominal Cash Flow Konfigurasi

\begin{tabular}{ccc}
\hline & \multicolumn{2}{c}{ Nominal Cash Flow } \\
\cline { 2 - 3 } Year & \multicolumn{2}{c}{ Current System } \\
\cline { 2 - 3 } & Annual $(\$)$ & Cumulative $(\$)$ \\
\hline 0 & 138.700 & 138.700 \\
1 & 13.538 & 125.162 \\
2 & 13.538 & 111.628 \\
3 & 13.538 & 98.086 \\
4 & 13.538 & 84.548 \\
5 & 338 & 84.210 \\
6 & 13.538 & 70.672 \\
7 & 13.538 & 57.134 \\
8 & 13.538 & 43.596 \\
9 & 13.538 & 16.520 \\
10 & 338 & 16.182
\end{tabular}
bahwa dari pembangkit limbah sekam padi dan jerami serta tenaga surya Dusun Pelanjau RT 13 Sukadamai juga berlangganan pada PLN sebagai catu daya maka tagihan yang harus dibayar Dusun Pelanjau RT 13 Sukadamai adalah sebesar $\$ 4.675$ untuk pembangkit biomassa dan \$ 1.755 untuk pembangkit PV dan biomassa setiap tahunnya.

Maksud dari perbandingan sistem optimal dengan grid adalah membandingkan payback period investasi kombinasi Generator dan PLTS apabila setiap bulannya tetap mengalokasikan anggaran sebagaimana berlangganan PLN. Sistem konfigurasi ini membutuhkan payback period selama 11 tahun dengan angsuran setiap tahunnya murni $100 \%$ dari surplus, sehingga apabila dibandingkan dengan grid asumsinya adalah "akan menjadi berapa lamakah payback period apabila setiap tahunnya juga membayar sebesar tagihan PLN?"

- Angsuran tahunan sistem konfigurasi biomassa

Angsuran / tahun (komparasi) $=\$ 13.538+\$ 4.675$

$$
=\$ 18.213
$$

- Angsuran tahunan sistem konfigurasi PV dan biomassa

Angsuran / tahun (komparasi) $=\$ 13.538+\$ 1.755$

$$
=\$ 15.293
$$

Journal of Applied Smart Electrical Network and Systems (JASENS) 
Melalui persamaan 2.10 nilai angsuran setiap nilai ekonomis yang sesuai dan akan didapatkan tujuan tahun untuk kasus perbandingan atau komparasi dengan untuk memenuhi kebutuhan listrik di Dusun Pelanjau RT grid dapat diketahui, yaitu sebesar \$ 18.213/tahun dan \$ 13 Sukadamai dan sebagai Desa Mandiri Energi secara 15.293/tahun. Dengan nilai initial capital yang sama model dan simulasi sudah hampir terpenuhi dikarenakan bisa mencari payback periodnya. Berikut adalah desa tersebut dapat menghasilkan energi listrik sebesar persamaanya : $40 \%$ dari total $100 \%$ konsumsi energi listrik.

- Payback perioed tahunan sistem konfigurasi biomassa

$$
\begin{aligned}
& \text { Payback period }=\frac{\$ 67.120}{18.231 / \text { tahun }} \\
& =3,7 \text { tahun }
\end{aligned}
$$

\section{Daftr Pustaka}

[1] "buku-teknis-membangun-sarana-prasarana gUNARLAN.pdf."

- Payback perioed tahunan sistem konfigurasi

PV dan biomassa

[2] T. Iskandar, "PEMANFAATAN LIMBAH PERTANIAN SEBAGAI ENERGI ALTERNATIF MELALUI KONVERSI THERMAL," vol. 12, no. 1, p. 6, 2012.

Payback period $=\frac{\$ 138.700}{15.293 / \text { tahun }}$

$$
=9,1 \text { tahun }
$$

Dari persamaan di atas didapatkan payback period selama 3,7 tahun untuk konfigurasi biomassa dan 9,1 tahun untuk konfigurasi PV dan biomassa. Jadi semakin besar angsuran maka payback period nya akan semakin cepat juga, begitupun sebaliknya.

\section{Kesimpulan}

Berdasarkan analisis hasil Optimasi Homer, tentang potensi kesediaan bahan bakar alternatif dari limbah sekam padi dan jerami di Kecamatan Tebas, dapat disimpulkan bahwa : energi terbarukan untuk pembangkit listrik Biomassa, jumlah energi listrik yang dihasilkan oleh model sistem dapat memenuhi kebutuhan energi listrik di Dusun Pelanjau RT 13 Sukadamai,dengan kedua sistem dapat dibandingkan, jika hanya menggunakan potensi limbah sekam padi dan jerami kita hanya memerlukan modal awal (initial capital) sebesar \$67.120. dan mememrlukan waktu balik modal yaitu sekitar 11 tahun tahun tanpa tagihan grid dan 5 tahun dengan tagihan grid. Sedangkan jika ingin menambahkan PV harus mengeluarkan modal sebesar \$ 138.700 dan memerlukan waktu balik modal yaitu selama 10 tahun tahun tanpa tagihan grid dan 9 tahun dengan tagihan grid. Maka dari itu sistem Homer menunjukan bahwa potensi limbah sekam padi dan jerami tanpa PV adalah konfogurasi yang paling optimal,konfigurasi sistem yang paling optimal untuk diterapkan di Dusun Pelanjau RT 13 Sukadamai, adalah $200 \mathrm{KW}$ converter, dan dengan berlangganan PLN 450 KW. Sistem optimal juga menunjukkan bahwa energi listrik yang dihasilkan dapat disalurkan ke grid (PLN), sehingga dapat menjadi pemasukan kas di Dusun Pelanjau RT 13 Sukadamai serta adanya konfigurasi sistem yang dihasilkan software homer energy menerapkan energy terbarukan sebagai pembangkitnya. Hal ini dibuktikan dengan komposisi penyusun konfigurasi sistem berupa Generator biomassa serta PLTS memiliki renewable fraction 56,8\%. Jadi energi alternatif yang di hasilkan dari radiasi sinar matahari serta limbah sekam padi dan jerami dapat menyediakan energi listrik untuk Dusun Pelanjau, Desa Bukit Sigoler, Kecamatan Kecamatan Tebas dan dapat memberikan PEMBAKARAN PADA BRIKET," vol. 4, no. 2, p. 6, 2014.

[4] U. B. Surono, "Peningkatan Kualitas Pembakaran Biomassa Limbah Tongkol Jagung sebagai Bahan Bakar Alternatif dengan Proses Karbonisasi dan Pembriketan,” J. Rekayasa Proses, vol. 4, no. 1, p. 6, 2010.

[5] I. Febijanto, "POTENSI BIOMASA INDONESIA SEBAGAI BAHAN BAKAR PENGGANTI ENERGI FOSIL," vol. 9, no. 2, p. 11, 2007.

[6] A. F. Mulyadi, I. A. Dewi, and P. Deoranto, "PEMANFAATAN KULIT BUAH NIPAH UNTUK PEMBUATAN BRIKET BIOARANG SEBAGAI SUMBER ENERGI ALTERNATIF," vol. 14 , no. 1 , p. 9.

[7] "Jalal Rosyidi Soelaiman - 081810201044.pdf."

[8] J. E. Putro, C. R. Handoko, H. Widodo, M. B. Rahmat, and A. Z. Arfianto, "Pemanfaatan Teknologi Tenaga Matahari sebagai Sumber Energi bagi Petani Porang di Magetan," p. 5, 2017.

9] F. Sheriff, D. Turcotte, and M. Ross, "PV TOOLBOX: A COMPREHENSIVE SET OF PV SYSTEM COMPONENTS FOR THE MATLAB®/SIMULINK® ENVIRONMENT," p. 12.

10] Wikipedia. 2019. Biomassa. (Online), http://id.wikipedia.org/wiki/Biomassa_(eklogi) diakses 23 November 2019. 